University of Montana

ScholarWorks at University of Montana

$5-1987$

\title{
A New Poem by Samuel Taylor Coleridge
}

James C. McKusick

University of Montana - Missoula, mckusickj@umkc.edu

Follow this and additional works at: https://scholarworks.umt.edu/eng_pubs

Part of the English Language and Literature Commons Let us know how access to this document benefits you.

\section{Recommended Citation}

McKusick, James C., "A New Poem by Samuel Taylor Coleridge" (1987). English Faculty Publications. 5.

https://scholarworks.umt.edu/eng_pubs/5

This Article is brought to you for free and open access by the English at ScholarWorks at University of Montana. It has been accepted for inclusion in English Faculty Publications by an authorized administrator of ScholarWorks at University of Montana. For more information, please contact scholarworks@mso.umt.edu. 
subject and the consequent need for interpretation. Wesley Trimpi quotes Cicero to the effect that "'Affection' is a change in the aspect of things due to time, or the result of actions or their management, or to the interests and desires of men, so that it seems that things should not be regarded in the same light as they have been or have generally been regarded." ${ }^{16}$ Interpretation is necessary, but not all interpretation is good; some, Cicero noted, may be fraudulent or oversubtle. The observers in Richard's court and the annotators of the court reports were aware of the danger, and commented accordingly. When, for example, Justice Thirning said, "il nous semble en ce caas qe la femme nest pas dowable par cause de cel lees" (cf. "By cause that it was old"), the annotator added "Hic patet expresse judicium . . fore recte": "And I seyde his opinion was good" (13RII, p. 55).

The printed law reports and records of the late fourteenth century represent no more than a small sample of what remains in manuscript, and although the manuscripts - especially of the reports - are extremely daunting, they were intended for reading. Modern scholars who read them will find in their old pages much new light on Chaucer.

Rutgers-The State University

16/ Wesley Trimpi, "The Quality of Fiction: The Rhetorical Transmission of Literary Theory," Traditio 30 (1974): 1-118, quoted at 32-33.

\section{A New Poem by Samuel Taylor Coleridge}

\section{James C. McKusick}

The poem published here is transcribed from an original holograph manuscript in the Berg Collection of the New York Public Library. The poem is a fragmentary verse translation of the Song of Deborah (from Judges 5). Its existence has been known to Coleridge scholars for several years, and its authenticity seems unquestionable. Kathleen Coburn mentions it in her edition of Coleridge's Notebooks: "The ms was with Coleridge's 'German Journal' of 1798-9 on acquisition by the library, but whether only accidentally there is not known. It appears to be fairly early." "To this remark I can add my own observation that the poem is written in a large hand characteristic of the early Coleridge; it is a fair copy that breaks off (in true Porlockian fashion) halfway through the song. The poem is printed below, followed by a critical commentary. ${ }^{2}$

1/ The Notebooks of Samuel Taylor Coleridge, ed. Kathleen Coburn (Princeton, N.J., 1957-), 3:4116n. (hereafter cited as Notebooks).

2 /Transcribed from an undated holograph manuscript with a shelf mark $(+++)$ in the Henry W. and Albert A. Berg Collection, New York Public Library. Published by permission of the library and the Astor, Lenox, and Tilden foundations.

(๑) 1987 by The University of Chicago. All rights reserved. 0026-8232/87/8404-0006\$01.00 


\section{The Poem}

The Song of Deborah, translated in the $\neq$ parallelisms of the Original / ( $\neq$ that is, so that each Line or member of a sentence is counter-balanced by the following, either by difference, or similitude, or by the repetition of the same thought in different words or with a different Image.)

Then sang Deborah,

And Barak, Abinoam's Son,

On that day sang they thus:

That the Leaders of Israel led on, And the People willingly followed Praise ye the Lord!

\section{I.}

Ye Monarchs, hear!

Give ear, ye Princes!

I sing to the Everlasting,

To the Everlasting will I play \& sing praises,

To the Lord God of Israel.

2

Lord God, Eternal!

When thou marchedst out from Seir,

When thou marchedst on thro' Edom,

The Earth trembled,

The Heavens dissolved,

The Clouds poured,

Mountains melted away from the Lord,

Mount Sina from before the face of Jehovah,

The Lord God of Israel.

\section{3}

In the days of Samgar, the Son of Anath,

In the days of Jael lay waste the High roads,

The Travellers went not save by crooked by-ways

Suspended were the assemblies of Israel,

They ceased, till I arose, Deborah,

Till that I arise, a mother in Israel.

4

To themselves they had chosen strange Gods;

And close to their gates came War.

Not a Shield was there seen, nor a Spear

Among the twice twenty Thousand of Israel.

\section{5}

My Heart, it swells high to the Rulers of Israel,

$\mathrm{O}$ ye, who offered yourselves freely among the People, Praise the Everlasting One. 
Ye that ride on white asses,

Ye that sit on seats of costly Coverings, or embroiderd Seats

Ye that walk on the High roads, frame a Song.

6

A Song for the Voice of the herdsmen, who beside thee draw wells

Draw water for the Herds \& Flocks!

For there will they sing the Deeds of Jehovah,

His deeds will the People of Israel praise

\section{Commentary}

Coleridge's translation of the Song of Deborah departs from the language of the Authorized Version of the Bible (AV) in ways that indicate he was comparing the English text with the Hebrew original, possibly with assistance from the Septuagint and various biblical commentaries. Collating the information from these sources, Coleridge translates the song in a way that exhibits both his knowledge of Hebrew and his characteristic directness of style. In stanza 3, for example, he alters the AV "by-ways" (Judg. 5:6) to read "crooked by-ways," adding the word "crooked" from the original Hebrew. In stanza 5, where the AV reads "ye that sit in judgment," Coleridge proposes two variant readings, "Ye that sit on seats of costly Coverings, or embroiderd Seats." These variant readings reflect his uncertainty over the meaning of an obscure Hebrew word that still perplexes commentators, but he is clearly striving for concreteness of diction. In stanza 6 , Coleridge rejects the AV reading of another obscure Hebrew word ("the noise of archers"), preferring instead to translate it as "the Voice of the herdsmen." This enables him to make sense of the Hebrew text by emphasizing the communal bond between the rulers, who "frame a Song," and the herdsmen, who sing it. Coleridge embellishes this image of the common folk with the line, "Draw water for the Herds \& Flocks," a phrase that does not occur in the AV and seems typically Romantic in its evocation of rustic life. Where the AV reads "inhabitants," Coleridge substitutes "assemblies" (stanza 3), again adding specificity and coherence to the poem by stressing its communal values.

In light of its association with Coleridge's German Journal, I would conjecture a date of circa 1799 for the poem. Coleridge had already evinced an interest in the poetic translation of biblical narrative in 1798, when he attempted to collaborate with Wordsworth on a poem entitled "The Wanderings of Cain." This project was soon abandoned as impractical, and The Rime of the Ancient Mariner was written instead, a poem whose biblical echoes have often been remarked. ${ }^{3}$ Coleridge's interest in biblical translation was heightened by his exposure to the emerging discipline of Germanic philology at the University of Göttingen in 1799. While in Germany, he made a verse translation from Otfrid's paraphrase of the gospel, a work he later described in terms that might apply equally well to his translation of the Song of Deborah: "Most interesting is it to consider the effect, when the feelings are wrought above the natural pitch by the belief in something mysterious, while all

3 /"The Wanderings of Cain" is printed in The Complete Poetical Works of Samuel Taylor Coleridge, ed. Ernest H. Coleridge (Oxford, 1912), 1:285-92 (hereafter cited as $P W$ ). Biblical echoes in Coleridge's poetry are discussed by Murray Roston, Poet and Prophet: The Bible and the Growth of Romanticism (London, 1965), pp. 172-79. 
the images are purely natural." ${ }^{4}$ This combination of purely natural images with a belief in a mysterious or transcendent power is what intrigued Coleridge about biblical poetry generally.

While attending the University of Göttingen, Coleridge was particularly stimulated by the lectures of Johann Gottfried Eichhorn, who was widely known as the founder of the Higher Criticism, a textually oriented historical study of the Bible. ${ }^{5}$ Although Coleridge was wary of Eichhorn's alleged atheistic tendencies, he was entirely in agreement with Eichhorn's reading of the Old Testament as a collection of documents written by human authors in concrete historical situations, and he spent much of his later career battling the "bibliolatry" of theologians who would effectively deny that historical setting by attributing the Bible to a divine Ventriloquist. In his Confessions of an Inquiring Spirit (written about 1825), Coleridge uses the Song of Deborah to defend his theory of human authorship. Deborah, he says, "was a mother in Israel; and with a mother's heart and a patriot's love, she had shot the light of love from her eyes, and poured the blessings of love from her lips, on the people that had jeoparded their lives unto the death against the oppressors," while she precipitated "curses on the selfish and coward recreants who came not to the help of the Lord." Only by bearing in mind her "age, country, and circumstances" can we hope to reach a sympathetic understanding of this passionate biblical heroine:

As long as I have the image of Deborah before my eyes, and while I throw myself back into the age, country, circumstances of this Hebrew Bonduca in the not yet tamed chaos of the spiritual creation;- as long as I contemplate the impassioned, high-souled, heroic woman in all the prominence and individuality of will and character,- I feel as if I were among the first ferments of the great affections - the protoplastic waves of the microcosmic chaos, swelling up against - and yet towards - the outspread wings of the Dove that lies brooding on the troubled waters. So long, all is well,- -all replete with instruction and example.... in the self-oblivion of these heroes of the Old Testament, their elevation above all low and individual interest, above all, in the entire and vehement devotion of their total being to the service of their divine Master, I find a lesson of humility, a ground of humiliation, and a shaming, yet rousing, example of faith and fealty. ${ }^{6}$

Only on these grounds can the violent imagery and vindictive attitude of the Song of Deborah have any redeeming spiritual value; these are what Coleridge feels hardpressed to justify and perhaps what led him to abandon his translation before it was completed.

Throughout his translation, Coleridge seeks to establish the historical specificity called for by the Higher Criticism by presenting Deborah as a woman exalted by the passions of her era and concerned for the destiny of Israel as a community

4/Samuel Taylor Coleridge, Biographia Literaria, ed. James Engell and W. Jackson Bate (Princeton, N.J., 1983), 1:208n.

5/Coleridge mentions his acquaintance with Eichhorn in a letter of May 6, 1799: "The Professors here are exceedingly kind to all the Englishmen; but to me they pay [the most] flattering attention-Especially, Blumenbach and Eichhorn" (Collected Letters of Samuel Taylor Coleridge, ed. Earl L. Griggs [Oxford, 1956], 1:494; hereafter cited as $C L$ ). Coleridge's relation to the Higher Criticism is discussed by Anthony J. Harding, Coleridge and the Inspired Word (Kingston, Ontario, 1985), pp. 75-83. Coleridge's annotations to the works of Eichhorn are printed in Marginalia, ed. George Whalley (Princeton, N.J., 1985), 2:369-520 (hereafter cited as Marginalia).

6/ Confessions of an Inquiring Spirit, letter 3, Complete Works of Samuel Taylor Coleridge, ed. W. G. T. Shedd (New York, 1853), 5:592-93. 
united by its faith in God. Coleridge's translation agrees in some respects with Eichhorn's reading of the Old Testament since he departs from the AV translation of "Jehovah" as "Lord" and instead uses "the Everlasting" (stanzas 1, 5) and "Lord God, Eternal" (stanza 2). Eichhorn, in his Einleitung ins Alte Testament (1787), similarly translates the word "Jehovah" as "the one who remains immutable (unveränderlich) in his intent." Eichhorn's lectures may also have alerted Coleridge to the importance of biblical parallelism, a topic much discussed in the German academy at this period.

The concept of parallelism was first used by Robert Lowth in his Praelectiones de Sacra Poesi Hebraeorum (1753) to explain what was "poetic" about a poetry that lacked any apparent rhyme or meter. ${ }^{8}$ Lowth's book marked a genuine breakthrough in biblical studies, and its findings were widely accepted by his contemporaries in England and Germany. Coleridge's prefatory note conveys the pith of the concept, namely, "that each Line or member of a sentence is counter-balanced by the following, either by difference, or similitude, or by the repetition of the same thought in different words or with a different Image." Lowth argues that a faithful English translation must attempt to preserve the original line divisions, which have been obscured by the scribal transmission of texts and by prose translations such as the AV and no less by the elegant but classically influenced verse translations of such authors as Milton and Pope. Lowth himself composed an English verse translation of the book of Isaiah which was printed in a sumptuous quarto edition in 1778. Lowth's verse translation differs from all previous biblical translations in its attempt to preserve the parallelisms of the Hebrew in unrhymed lines of variable measure. This influential and lucrative publishing venture may well have encouraged Coleridge to try his hand at translating the Song of Deborah, a work that Lowth had praised as exemplary of Hebrew sublimity. ${ }^{9}$

Coleridge was acquainted with Lowth's works quite early in his career. In his 1795 Lectures on Revealed Religion, he quotes a long passage from Isaiah in Lowth's translation. He clearly regarded Lowth's version as an improvement over the AV: "The passage is well known yet as it is in some parts falsely rendered in our Translation, I shall repeat it as collected from later and more accurate Versions." ${ }^{10}$

7/Johann Gottfried Eichhorn, Einleitung ins Alte Testament, 2d ed. (Leipzig, 1787), 2:329. A decade after his departure from Germany, Coleridge had second thoughts about Eichhorn's reading of Exodus: "Nay, I doubt the interpretation of JEHOVAH, as = the immutable, \& believe it rather to refer to Ex. C.III.14" (Marginalia, 2:392). This marginal annotation indicates that Coleridge now interprets the word "Jehovah" in the light of Exod. 3:14, where God's name is revealed to be "I AM THAT I AM." By 1810, Coleridge had become sufficiently steeped in the "I AM" philosophy of the post-Kantians to reject the reading of "Jehovah" that he had previously used in his own translation of the Song of Deborah. This would tend to confirm an early date for the poem.

8/Robert Lowth, Praelectiones de Sacra Poesi Hebraeorum (Oxford, 1753). These lectures were reprinted at Göttingen in 1758-61, with notes added by Johann David Michaelis. The Göttingen edition provided the basis for an English translation: Lectures on the Sacred Poetry of the Hebrews; Translated from the Latin of the Right Rev. Robert Lowth...to which are added, the Principal Notes of Professor Michaelis (London, 1787). Lowth's historical approach to the Bible was widely influential in Germany; it contributed to the Higher Criticism of Eichhorn and inspired Johann Gottfried von Herder's Vom Geist der Ebraischen Poesie (Dessau, 1782-83).

9/"Another specimen of the perfectly sublime Ode will be found in the triumphal Ode of Deborah" (Lowth, Lectures on the Sacred Poetry of the Hebrews, 2:257 [lecture 28]; see also 1:378 [lecture 17]).

10/Samuel Taylor Coleridge, Lectures 1795: On Politics and Religion, ed. Lewis Patton and Peter Mann (Princeton, N.J., 1971), p. 153. 
Coleridge quotes the fourth Servant Song (Isa. 52:13-53:12) almost verbatim from Lowth, making only a few deletions and rearrangements. His declared intention in quoting this passage is to demonstrate its prophetic truth as a foreshadowing of Christ, but perhaps equally remarkable is its evocative poetic power, the result of its concrete imagery and marked parallelisms. An extract from the passage, retaining Lowth's original line divisions, may serve to illustrate these qualities:

53:1 Who hath believed our report;

And to whom hath the arm of JEHOVAH been manifested?

2 For he groweth up in their sight like a tender sucker;

And like a root from a thirsty soil:

He hath no form, nor any beauty, that we should regard him;

Nor is his countenance such that we should desire him.

3 Despised, nor accounted in the number of men;

A man of sorrows, and acquainted with grief;

As one that hideth his face from us:

He was despised, and we esteemed him not.

Lowth's line divisions make apparent the principle of parallelism at work here. The lines fall neatly into pairs according to their semantic content and syntactic structure. The first member of each pair makes a statement which the second member elaborates, illustrates, or further specifies. This kind of structure is what Lowth, in the preliminary dissertation to his translation of Isaiah, terms "synonymous parallelism," and his remarks are worth quoting at some length since, according to $O E D$, they constitute the first usage of "parallelism" in English (though Lowth had expressed the same concept much earlier, as parallelismus membrorum, in his Praelectiones): "The correspondence of one Verse, or Line, with another, I call Parallelism. When a proposition is delivered, and a second is subjoined to it, or drawn under it, equivalent, or contrasted with it, in Sense; or similar to it in the form of Grammatical Construction - these I call Parallel Lines; and the words or phrases, answering one to another in the corresponding Lines, Parallel Terms." 11 Lowth's theory is not one of mindless repetition but of artful variation in sense and construction. It allows for contrast as well as equivalence in the parallel lines. Some possibilities of variation are apparent in the lines from Isaiah quoted above. The first pair of lines (53:1) poses two rhetorical questions that imply the same answer, "no one." The second pair of lines (53:2) is also parallel in grammatical construction, though with the main clause elided in the second line and the figurative description of the Servant, "like a root from a thirsty soil," correspondingly elaborated. In 53:3, four lines are joined in a chiastic structure, with the first and last echoing the term "despised," while the middle two lines describe the Servant's sorrow, grief, and isolation. Lowth's theory of parallelism is supple enough to account for such chiastic structures; he specifically mentions "parallels consisting of four lines: two Distichs being so connected together, by the sense and construction, as to make one Stanza." 12 Lowth's scheme seeks to do justice to the variety and complexity of parallel structures in Hebrew poetry; and while few modern scholars would be

11/Robert Lowth, Isaiah. A New Translation; With a Preliminary Dissertation, and Notes Critical, Philological, and Explanatory (London, 1778), p. x.

12/lbid., p. xvi. 
satisfied with his descriptive terminology, he still provides a point of departure for all subsequent discussions of biblical parallelism. ${ }^{13}$

It is questionable whether Coleridge fully recognized the importance of Lowth's theory of parallelism as early as 1795 since in his quotation of Lowth's Isaiah he runs the lines together as prose, thus obscuring their parallel structure. But he did retain an interest in Lowth, for in September 1796 he borrowed "Lowth's Praelections" from the Bristol library. ${ }^{14}$ These Latin lectures contain a much fuller account of Lowth's theories. Coleridge could have found a lengthy account of biblical parallelism, along with a detailed analysis of "the sublime style" in Isaiah and the Song of Deborah. Coleridge's reading of these lectures may well have sparked his interest in parallelism as a poetic technique, as well as his interest in translating the Bible into English verse. He was particularly receptive to Lowth's enthusiastic description of Isaiah as a sublime poet. In a letter of December 17, 1796, Coleridge ranks Isaiah even higher than Milton on the scale of poetic sublimity: "Is not Milton a sublimer poet than Homer or Virgil? Are not his Personages more sublimely cloathed? And do you not know, that there is not perhaps one page in Milton's Paradise Lost, in which he has not borrowed his imagery from the Scriptures?-I allow, and rejoice that Christ appealed only to the understanding \& the affections; but I affirm that, after reading Isaiah, or St Paul's Epistle to the Hebrews, Homer \& Virgil are disgustingly tame to me, \& Milton himself barely tolerable." 15 Coleridge evidently concurs with Lowth's view of Isaiah, "whom I do not scruple to pronounce the sublimest of poets." 16

Coleridge's style in his translation of the Song of Deborah closely resembles that of Lowth in his translation of Isaiah. In particular, Coleridge uses unrhymed lines of variable measure to highlight the parallel structures of the Hebrew original. Where the AV is merely redundant, as in its repetition of the verb "dropped" (Judg. $5: 4)$, Coleridge varies the parallel verbs to achieve an intricate pattern of semantic differences: "The Earth trembled, / The Heavens dissolved, / The Clouds poured" (stanza 2). While increasing the lexical variation in these three lines, Coleridge also heightens their grammatical and metrical uniformity, so that the effect of the stanza is one of local variety within a larger structure of balance and symmetry.

A more daring instance of grammatical variation is apparent in Coleridge's counterpointing of past and present tense forms in stanza 3: "They ceased, till I arose, Deborah, / Till that I arise, a mother in Israel." At this point the Hebrew text simply repeats a preterite form, and the AV likewise repeats the past tense form "arose." Coleridge, by varying the tense of the verb "arise," discovers an English

13/An excellent discussion of biblical parallelism may be found in Robert Alter, The Art of Biblical Poetry (New York, 1985). Alter, like Coleridge, stresses the element of difference between supposedly synonymous terms. Even in the case of biblical parallelism, where verbatim repetition of lexical elements is not uncommon, Alter argues that some degree of "semantic modification" always takes place (p. 10). "Synonymous parallelism," in short, is something of a misnomer since its usual effect is one of desynonymization (a term Coleridge first coined in 1803-see Notebooks [n. I above], 1:1336, and Biographia Literaria, 1:82). Further historical background, and a detailed critique of Lowth, may be found in James Kugel, The Idea of Biblical Poetry: Parallelism and Its History (New Haven, Conn., 1981).

14/George Whalley, "The Bristol Library Borrowings of Southey and Coleridge, 1793-8," Library, 5th ser., 4 (1949): 114-31 (item 84).

15/CL (n. 5 above), 1:281.

16/ Lowth, Lectures on the Sacred Poetry of the Hebrews, 1:294 (lecture 13). 
equivalent for the fluidity of tense distinctions in Hebrew verbs, a fluidity that often lends even remote historical events a sense of immediacy. By varying the English verb tenses, Coleridge implies that Deborah's prophetic calling was not an isolated event but is part of a larger providential process that continues into the present moment. Such a variation of tenses occurs frequently in the Bible, as Coleridge could have learned by reading virtually any Hebrew grammar book. In a Hebrew grammar of 1549 , David Kimhi states that the preterite is often put in place of the future, and the future in place of the preterite, "especially in the Prophets, on account of the certainty of the matter." 17 The passage from Isaiah quoted above $(53: 1-3)$ shows a counterpointing of past and present tense forms, perhaps also to impart a sense of inevitability to prophetic vision.

The Song of Deborah plays an important role in the development of Coleridge's practical criticism. Both Coleridge and Wordsworth are fond of citing this song as an example of the highest kind of poetry. In his 1800 note to "The Thorn," Wordsworth argues that "repetition and apparent tautology are frequently beauties of the highest kind" as a result of "the interest which the mind attaches to words, not only as symbols of the passion, but as things, active and efficient, which are of themselves part of the passion. The truth of these remarks might be shewn by innumerable passages from the Bible and from the impassioned poetry of every nation." Wordsworth quotes several verses from the AV text of the Song of Deborah, adding: "See also the whole of that tumultuous and wonderful Poem." 18 Coleridge replies to this note in the Biographia Literaria (London, 1817), distinguishing between the "unmeaning repetitions" of the garrulous narrator of "The Thorn" and the merely "apparent tautologies of intense and turbulent feeling, in which the passion is greater and of longer endurance, than to be exhausted or satisfied by a single representation of the image or incident exciting it. Such repetitions I admit to be a beauty of the highest kind; as illustrated by $\mathrm{Mr}$. Wordsworth himself from the Song of Deborah." ${ }^{19}$ For Coleridge, then, true poetic eloquence is distinguished from mere prosaic redundancy by its passionate intensity.

Coleridge often connects the Song of Deborah with the concept of the sublime. In a notebook entry of 1808-11, evidently used as the basis for his lectures on Shakespeare, he praises the pathos and sublimity of "Deborah's Song-Nature is the Poet here." ${ }^{20}$ In another entry of 1811, he describes "that Law of Passion which inducing in the mind an unusual activity seeks for means to waste its superfluityin the highest $\&$ most lyric kind, in passionate repetition of a sublime Tautology (as in the Song of Debora)." Coleridge here identifies "sublime Tautology" as a rhetorical figure that bespeaks both the poverty of language and the overwhelming power of the emotions it seeks to express. Poetic sublimity results from a crisis of mental activity finding volcanic outlet in language.

17/David Kimhi, Hebraicarum institutionum Libri IIII, Sancte Pagnino Lucensi authore, Ex R. Dauid Kimhi (Paris, 1549), lib. III, cap. xii, p. 259. This Hebrew grammar served as the basis for most later ones. It is uncertain which Hebrew grammar Coleridge actually used, although we know that he studied the language under James Boyer's tutelage at Christ's Hospital (Biographia Literaria, 1:11). In 1817 he translated into English verse a Hebrew dirge by his friend Hyman Hurwitz ( $P W[\mathrm{n} .3$ above], 1:433).

18/The Poetical Works of William Wordsworth, ed. Ernest de Selincourt (Oxford, 1944), 2:513.

19/Biographia Literaria, 2:57.

20/Notebooks, 3:3247.

21/Ibid., 3:4113. 
Recent scholarship on the Romantic period has examined the concept of the sublime from various points of view. Thomas Weiskel develops a psychological model that depends largely on the distinction between the sublime and the beautiful established by Burke and Kant. ${ }^{22}$ Raimonda Modiano seeks to correct Weiskel's view by introducing a third term, the picturesque, and by tracing Coleridge's response to the presentation of landscape in art. ${ }^{23}$ Although Modiano is more comprehensive than Weiskel in her treatment of Coleridge's theory of the sublime, nevertheless her account remains limited by its focus on what Hugh Blair, in his Lectures on Rhetoric (1783), termed "Sublimity in Objects," while she neglects "The Sublime in Writing." In his lecture on this topic, Blair notes that "Of all writing . . . the Sacred Scriptures afford us the highest instances of the Sublime." ${ }^{24}$ If indeed the biblical model of sublime writing is crucial to Coleridge's poetics, then his translation of the Song of Deborah may prove to be a missing link in current theoretical debates concerning the nature and origin of the Romantic sublime. ${ }^{25}$

\section{University of Maryland Baltimore County}

22/Thomas Weiskel, The Romantic Sublime (Baltimore, 1976).

23/Raimonda Modiano, Coleridge and the Concept of Nature (Tallahassee, Fla., 1985).

24/Hugh Blair, Lectures on Rhetoric and Belles Lettres (London, 1783), lecture 4. Blair's lectures were familiar to Wordsworth and Coleridge. In January 1798 Coleridge borrowed "Vol 2nd Blair's Lectures" from the Bristol Library (see Whalley, item 103). This volume includes lecture 41, "The Poetry of the Hebrews," largely a synopsis of Lowth's views.

25/On this topic, see also Albert O. Wlecke, Wordsworth and the Sublime (Berkeley, 1973); Stuart A. Ende, Keats and the Sublime (New Haven, Conn., 1976); Angela Leighton, Shelley and the Sublime (Cambridge, 1984). 